\title{
Antibodies to lens antigens in cataract and after cataract surgery
}

\author{
STEEN HOLST NISSEN, ${ }^{1}$ PAUL ANDERSEN, ${ }^{23}$ AND \\ HANS MOGENS KERZEL ANDERSEN ${ }^{3}$ \\ From the ${ }^{1}$ Department of Ophthalmology, the ${ }^{2}$ Chest Clinic, Aarhus Municipal Hospital, \\ and the ${ }^{3}$ Institute of Microbiology, University of Aarhus, Denmark
}

SUMMARY By means of an enzyme-linked immunosorbent assay (ELISA) antibodies to whole lens homogenate were found in $50.0 \%$ of 38 patients with senile cataract and in $57.3 \%$ of 75 controls. The antibody titres were in the range of $10-160$ in both groups. IgG antibodies occurred in $44.7 \%$ of patients and in $45.3 \%$ of controls, whereas IgM antibodies were found in $21.1 \%$ of the patients and in $40.0 \%$ of the controls (not significant). Postoperative uveitis occurred in $6(31.6 \%)$ of 19 patients, who had antibodies in serum prior to the operation and in only $2(10.5 \%)$ of 19 antibodynegative patients $(\mathrm{P}=0 \cdot 10)$.

The human lens is developed and isolated from the fetal circulation around the tenth week of gestation. Lens antigens have therefore been sequestered from the immune system and may thus have escaped induction of immunological tolerance. Leakage of antigens from the lens might therefore lead to induction of an autoimmune reaction and possibly to lens-induced uveitis. ${ }^{2}$ In accordance with this concept lens antibodies were demonstrated after extracapsular extraction and in uveitis. ${ }^{134}$ However lens antibodies did not appear in all patients undergoing extracapsular lens extraction or with injury to the lens, while they were detected in a high percentage of normal subjects. ${ }^{56}$ These observations would be inconsistent with the concept of lenticular antigens as being 'not-self' or sequestered antigens. ${ }^{26}$

The significance of lens antibodies in cataract and postoperative uveitis is not clear, and it would be of interest to study the immunoglobulin (Ig) classes and titres of lens antibodies in these conditions. ${ }^{7}$ By means of an enzyme-linked immunosorbent assay (ELISA) we have investigated the occurrence of IgG and IgM antibodies to lens in patients with senile cataract and in controls. In order to study the significance of antibodies in postoperative uveitis, patients with cataract were studied both before and after lens extraction.

\section{Material and methods}

SUBJECTS

A total of 280 sera from 118 subjects were investi-

Correspondence to Dr S. H. Nissen, Department of Ophthalmology, Aalborg Sygehus Syd, 9000 Aalborg, Denmark. gated for lens antibodies. The subjects were divided into 3 groups.

Group 1. Thirty-eight patients with senile cataract aged 56 to 86 years (mean age $72 \cdot 7$ years). The group comprised 25 women and 13 men. Sixteen had mature, 5 hypermature, 7 nuclear, 6 cortical, and 4 both nuclear and cortical cataract. All patients underwent intracapsular lens extraction, and blood samples were obtained preoperatively and 1 and 5 weeks after the operation. All patients were examined for uveitis by biomicroscopy before and 1 week after the operation. The degree of uveitis was rated according to the aqueous flare. Only patients having sufficient intraocular reactions to require steroid treatment were regarded as having uveitis.

Group 2. Five patients with recent perforating injury to the lens. Sera from these patients were obtained within 25 hours of the injury and 1-2 and 6 weeks postoperatively.

Group 3. Seventy-five control persons (37 women and $38 \mathrm{men}$ ) aged 21 to 76 years (mean age 48.5 years). The group comprised 15 medical students aged 21-26 years, 26 blood donors aged 22-65 years, from the Blood Bank, Aarhus Municipal Hospital, and 34 hospitalised patients aged 40-76 years. The subgroup of medical students and blood donors stated that they were healthy, but they were not examined for cataract. The subgroup of hospitalised patients were admitted with symptoms of gastrointestinal upset, cardiovascular disease, arthrosis, or minor psychiatric illness. They did not have hepatic, autoimmune, or infectious diseases. They were not examined for cataract.

All sera were stored at $-20^{\circ} \mathrm{C}$, and they were in- 
vestigated with the same antigen preparation during the same period of time.

\section{ANTIGENS}

Cataractous lenses removed after intracapsular lens extraction were stored at $-20^{\circ} \mathrm{C}$ until used. Frozen lenses were pooled, cut with a pair of scissors, and homogenised with a carbonate buffer (ph 9.6) in a Potter-Elvehjem homogeniser. The suspension was centrifuged at 3000 r.p.m. for $20 \mathrm{~min}$ to remove insoluble material. The supernatant soluble antigen was stored at $-20^{\circ} \mathrm{C}$. Prior to use the protein concentration was determined by the method of Lowry et al. ${ }^{8}$

\section{ANTISERA}

Rabbits were immunised with soluble lens antigens in complete Freund's adjuvant at weekly intervals for 12 weeks. They received $0.5 \mathrm{mg}, 1 \mathrm{mg}$, and $2 \mathrm{mg}$ of antigen per injection subcutaneously. Two weeks after the last injection the rabbits were bled and the sera were stored at $-20^{\circ} \mathrm{C}$. Rabbit antisera were used to determine the optimal conditions for the ELISA assay.

\section{DETECTION OF LENS ANTIBODIES}

Lens antibodies were detected by an enzyme-linked immunosorbent assay (ELISA) carried out according to standard procedures. ${ }^{9}$ Polystyrene tubes (LBK, Bromma, Sweden) were coated with $0.2 \mathrm{ml}$ antigen solution in carbonate buffer by incubation at room temperature for 2 hours and at $4^{\circ} \mathrm{C}$ overnight. The protein concentration of the antigen solution was $10 \mu \mathrm{g}$ per $\mathrm{ml}$, which was found to be optimal by chessboard titrations, The tubes were washed 3 times with phosphate-buffered saline with $0.05 \%$ Tween 20 , pH 7.2 (PBS-Tween). $0.2 \mathrm{ml}$ serum diluted 1:10 with PBS-Tween was added to the coated tubes and incubated at $37^{\circ} \mathrm{C}$ for 6 hours. After washing 3 times with PBS-Tween, $0.2 \mathrm{ml}$ of conjugate was added and the tubes were left overnight at $4^{\circ} \mathrm{C}$. The conjugates employed were swine antihuman IgG and antihuman IgM conjugated with alkaline phosphatase (Orion Diagnostics Oy, Finland) diluted in PBS-Tween. Excess conjugate was washed off and the tubes were rinsed in PBSTween. $0.2 \mathrm{ml}$ substrate solution (Sigma 104, phosphatase substrate tablets) containing $p$-nitrophenylphosphate in $1 \mathrm{~N}$ diethanolamine buffer, $\mathrm{pH}$ 10.0 at a concentration of $1 \mathrm{mg}$ per $\mathrm{ml}$ was added. The tubes were incubated at $37^{\circ} \mathrm{C}$ for $60 \mathrm{~min}$, and $0.6 \mathrm{ml} \mathrm{0.3} \mathrm{M} \mathrm{NaOH}$ was added. The liberated p-nitrophenolate was measured in a spectrophotometer at $399 \mathrm{~nm}$. The results were expressed as absorbance of the sample. Readings were between
Table 1 Occurrence of antibodies to human lens in patients with senile cataract and controls

\begin{tabular}{|c|c|c|c|c|}
\hline & $\begin{array}{l}\text { IgG antibody } \\
\text { positive }\end{array}$ & $\begin{array}{l}\text { IgM antibody } \\
\text { positive }\end{array}$ & $\begin{array}{l}\text { IgG and/or } \\
\text { IgM antibody } \\
\text { positive }\end{array}$ & $\begin{array}{l}\text { Antibody } \\
\text { negative }\end{array}$ \\
\hline $\begin{array}{l}\text { Patients } \\
\mathrm{n}=38\end{array}$ & $\begin{array}{l}44 \cdot 7 \% \\
n=17\end{array}$ & $\begin{array}{l}21 \cdot 1 \% \\
n=8\end{array}$ & $\begin{array}{l}50.0 \% \\
n=19\end{array}$ & $\begin{array}{l}50.0 \% \\
n=19\end{array}$ \\
\hline $\begin{array}{l}\text { Controls } \\
n=75\end{array}$ & $\begin{array}{l}45 \cdot 3 \% \\
n=34\end{array}$ & $\begin{array}{l}40.0 \% \\
n=30\end{array}$ & $\begin{array}{l}57 \cdot 3 \% \\
n=43\end{array}$ & $\begin{array}{l}42 \cdot 3 \% \\
n=32\end{array}$ \\
\hline
\end{tabular}

0 and 10 , and readings above 1.0 were considered positive. All positive sera were titrated in doubling dilutions from $1: 10$ to $1: 640$.

\section{Results}

Antibodies to lens antigens were detected with equal frequences in patients with senile cataract $(50.0 \%)$ and in controls $(57 \cdot 3 \%)$ (Table 1 ). IgG antibodies were found with equal frequencies in patients $(44.7 \%)$ and controls $(45.3 \%)$, while IgM antibodies occurred less often in patients with senile cataract $(21 \cdot 1 \%)$ than in normal controls $(40.0 \%)$. However, this difference was not significant (Table $1, \chi^{2}$ test, $0 \cdot 10>P>0.05)$. The antibody titres were generally low, and they were in the same range $(10-160)$ in both groups. A positive correlation between IgG and IgM antibodies was found in controls $\left(\chi^{2}\right.$ test, $0.01>P>0.001)$ but not in patients $\left(\chi^{2}\right.$ test, $0 \cdot 2>P>0 \cdot 1)$.

The antibody incidences in different types of cataract are shown in Table 2 . Lens antibodies occurred more frequently in hypermature cataract $(80 \%)$ than in the other types $(38 \%-57 \%)$, but the difference was not significant.

The lensectomy was uncomplicated in 34 cases and complicated in 4 cases. In 2 patients vitreous loss occurred. They were antibody-negative both before and after operation and did not develop postoperative uveitis. Rupture of the lens capsules occurred in 2 other patients. One of these also had vitreous loss. In these cases antibodies were present before and after operation. They developed uveitis

Table 2 Lens antibodies in different types of senile cataract

\begin{tabular}{lcclll}
\hline & $\begin{array}{l}\text { Nuclear } \\
\text { cataract }\end{array}$ & $\begin{array}{l}\text { Cortical } \\
\text { cataract }\end{array}$ & $\begin{array}{l}\text { Cortical } \\
\text { and } \\
\text { nuclear } \\
\text { cataract }\end{array}$ & $\begin{array}{l}\text { Mature } \\
\text { cataract }\end{array}$ & $\begin{array}{l}\text { Hyper- } \\
\text { mature } \\
\text { cataract }\end{array}$ \\
\hline $\begin{array}{l}\text { No. with } \\
\text { antibody/ } \\
\text { total }\end{array}$ & $4 / 7-57 \%$ & $3 / 6-50 \%$ & $2 / 4-50 \%$ & $6 / 16-38 \%$ & $4 / 5-80 \%$ \\
\hline
\end{tabular}


Table 3 Correlation between lens antibodies in preoperative blood samples and postoperative uveitis

\begin{tabular}{ll}
\hline Antibody prior to operation & No. with postoperative uveitis \\
\hline $\begin{array}{l}\text { Antibody-positive } \\
\mathrm{n}=19\end{array}$ & $6-31.6 \%$ \\
$\begin{array}{l}\text { Antibody negative } \\
\mathrm{n}=19\end{array}$ & $2-10.5 \%$ \\
\hline
\end{tabular}

postoperatively, but their antibody titres did not change.

Postoperative uveitis occurred in 6 of 19 patients $(31.6 \%)$ who had lens antibodies in preoperative blood specimens and in only 2 of 19 who were antibody-negative prior to the operation $(10.5 \%)$. This difference was not significant (Table 3, Fisher's exact test, $P=0 \cdot 12$ ). It was not possible to demonstrate any correlation between increasing antibody titres and postoperative uveitis. The titre rose in 1 of 8 patients with postoperative uveitis $(12.5 \%)$ and in 8 of 30 patients $(26.7 \%)$ who did not develop uveitis.

Among 5 patients with perforating injury to the lens 2 were antibody-negative and 3 were antibodypositive on the first day after the trauma. In 1 patient the antibody titre rose from 10 to 40 after 6 weeks, whereas in the remaining 4 patients the antibody titres did not change during the following 6 weeks, though in all of them a uveal reaction developed 1 week after the trauma.

\section{Discussion}

The present findings of low lens antibody titres in $57 \%$ of blood donors are in agreement with previous studies in which antibodies were detected in about $50 \%$ of normal subjects ${ }^{56}$ but in contrast to others in which much lower frequencies were found. ${ }^{4}$ These discrepancies could be due to differences in the methods or the antigen preparations used for the antibody determination. In patients with cataract lens antibodies were not detected at all by double immunodiffusion ${ }^{10}$ and in a very low percentage by passive haemagglutination. ${ }^{1}$ However, in another study ${ }^{6}$ alpha crystallin antibodies were detected in about half of both patients with cataract and controls with clear lenses. Using an ELISA technique we also found lens antibodies in about half of both patients with cataract and controls. The titres were low, and they were in the same range in the 2 groups.

Hackett and Thompson ${ }^{5}$ demonstrated that lens antibodies were beta-2M-globulins (IgM). We found IgM antibodies slightly more often in controls than in patients with cataract, whereas IgG antibodies occurred with the same incidence in the 2 groups. Thus, it was not possible to demonstrate any difference in antibody incidence, in the range of titres, or in antibody classes between patients with cataract and controls. The hypothesis that antibodies should be of significance in pathogenesis of senile cataract could not, therefore, be supported.

However, antibodies might be of importance in some types of cataract and not in others. Antibodies occurred at a higher prevalence in the small group of hypermature cataract than in the other types. It is also possible that antibodies were present at a higher concentration in the aqueous humour than in the serum of patients with cataract. ${ }^{11}$

Finally, lens antibodies in patients with cataract and controls may have different specificities. It has previously been shown that whole lens homogenate contains several antigens, including some which cross-react with extraocular tissue constituents. ${ }^{2}$ Non-organ-specific antibodies have previously been demonstrated in normal sera by indirect immunofluorescence, ${ }^{12} 13$ and it is possible that such antibodies were demonstrated by the present method. However, specific alpha crystallin antibodies were also detected with equal frequencies in patients with cataract and controls. ${ }^{6}$

The failure to demonstrate antibodies after injury to the lens, and the finding of equal incidences of antibody in cataract patients and controls, does not agree with the concept that all lenticular antigens are 'not-self' or sequestered. ${ }^{26}$

The significance of lens antibodies in postoperative uveitis is not clarified. The presence of antibodies in preoperative blood samples may indicate an already established hypersensitivity to lenticular antigens. Patients with antibodies might, therefore, and presumably more likely than antibody-negative patients, develop immunologically mediated postoperative complications after lensectomy. This view may be supported by the present study, in which postoperative uveitis occurred most frequently in patients with antibodies in preoperative blood specimens. However, the difference was not significant, and further investigations with purified antigens might help elucidate this problem.

Dr T. Olsen assisted in the statistical calculations.

This work was supported by grants from the Danish Medical Research Council (512-15580), Komiteen til forebyggelse af blindhed, and the P. Carl Petersens Fund.

\section{References}

'Wirotsko E, Spalter HF. Lens-induced uveitis. Arch Ophthalmol 1967; 78: 1-7.

${ }^{2}$ Rahi AHS, Misra RN, Morgan G. Immunopathology of 
the lens III. Humoral and cellular immune responses to autologous lens antigens and their roles in ocular inflammation. Br J Ophthalmol 1977; 61: 371-9.

${ }^{3}$ Perkins ES, Wood RM. Autoimmunity in uveitis. $\mathrm{Br} J$ Ophthalmol 1964; 48: 61-9.

${ }^{4}$ Luntz MH. Antiuveal and anti-lens antibodies in uveitis and their significance. Exp Eye Res 1968; 7: 561-9.

${ }^{5}$ Hackett E, Thompson A. Anti-lens antibody in human sera. Lancet 1964; ii: 663-6.

Sandberg HO, Closs $\mathrm{O}$. The humoral immune response to alpha, beta and gamma crystallins of the human lens. Scand J Immunol 1979; 10: 549-54.

'Editorial: The case against the lens. $\mathrm{Br} J$ Ophthalmol $1977 ; 61: 369-70$.

${ }^{8}$ Lowry OH, Rosebrough NJ, Farr AL, Randall RJ. Protein measurement with the Folin phenol reagent. J Biol Chem $1951 ; 193$ : 265-75.
${ }^{9}$ Voller A, Bidwell DE, Bartlett A. Enzyme immunoassays in diagnostic medicine. Theory and practice. Bull WHO 1976; 53: 55-65.

${ }^{10}$ Halbert SP, Locatcher-Khorazo D, Swick L, Witmer R, Seegal B, Fitzgerald P. Homologous immunological studies of ocular lens. II. Biological aspects. J Exp Med 1957 ; 105: 453-62.

${ }^{11}$ Witmer R. Zur Frage der Auto-Immunerkrankung des Auges: die Phako-Antigene Uveitis. Int Arch Allergy Appl Immunol 1964; 24 (Suppl.): 58-64.

${ }^{12}$ Shu S, Nisengard RJ, Hale WL, Bentner EH. Incidence and titres of antinuclear, antismooth muscle, and other autoantibodies in blood donors. J Lab Clin Med 1975; 86: 259-65.

${ }^{13}$ Andersen P. Correlation of smooth-muscle and nuclear antibodies in normal subjects. Clin Exp Immunol 1977; 27: 74-7. 